\title{
Oxidative cleavage of alkenes catalyzed by a water/organic soluble manganese porphyrin complex
}

\author{
Shiuh-Tzung Liu, ${ }^{*}$ K. Venugopal Reddy and Rung-Yi Lai \\ Department of Chemistry, National Taiwan University, Taipei 106, Taiwan
}

Received 11 August 2006; revised 12 December 2006; accepted 13 December 2006

Available online 8 January 2007

\begin{abstract}
Tetrakis(4-hydroxyphenyl)porphyrin [TPP- $\left.(\mathrm{OH})_{4}\right]$ was modified with poly(ethylene glycol) chain as four side arms, such that this compound is soluble in both organic and water solutions. Complexation of this porphyrin with manganese metal ions resulted in the formation of $\mathrm{MnCl}-\mathrm{TPP}-\left(\mathrm{PEO}_{750}\right)_{4}$. This complex proved to be an excellent catalyst for the oxidative cleavage of $\mathrm{C}=\mathrm{C}$ bonds, yielding the corresponding carbonyl compounds with sodium periodate as an oxidant. Mechanistic pathway for this cleavage is discussed. (c) 2006 Elsevier Ltd. All rights reserved.
\end{abstract}

\section{Introduction}

Metalloporphyrin species exist ubiquitously in nature and have found a broad spectrum of applications. Amongst, for example, the modeling of cytochrome P-450 for oxygenation of hydrocarbons has received much attention over decades. $^{1-24}$ As for the chemical reaction, great efforts have been made to develop new metalloporphyrin-based catalytic systems for the oxidation process, aiming at a higher degree of chemo- and stereoselectivities as well as efficiency under mild conditions. ${ }^{1-5}$ In this context, epoxidation and hydroxylation of alkenes catalyzed by metal porphyrin complexes have been a major focus. ${ }^{6-24}$

Recently, porphyrin-Fe and porphyrin-Mn complexes and their corresponding oxo species, ${ }^{15-17}$ heterogeneously supported manganese porphyrins ${ }^{18-20}$ and poly(ethylene glycol) (PEO) side-chain manganese porphyrins ${ }^{21}$ have been widely used as catalysts for either epoxidation or hydroxylation of alkenes under ambient temperatures. However, to our knowledge, there is no precedence concerning the use of manganese porphyrin complexes in the catalytic cleavage of $\mathrm{C}=\mathrm{C}$ bonds. ${ }^{22,23}$ To obtain aldehydes from olefins that are not fully substituted, two common methods are ozonization of olefins followed by a reductive workup and oxidative cleavage with osmium tetraoxide-sodium periodate, both of which, however, required stringent reaction conditions. ${ }^{22,23}$ For the safety concern, chemists have been developing alternative methods for the cleavage of $\mathrm{C}=\mathrm{C}$, especially on the basis of catalytic approach. ${ }^{23}$ Herein we report the

\footnotetext{
Keywords: Oxidative cleavage; Porphyrin; Manganese; Olefin.

* Corresponding author. Tel.: +88622366 0352; fax: +88622363 6359; e-mail: stliu@ntu.edu.tw
}

preparation of a water/organic soluble metal porphyrin complex $\mathrm{MnCl}-\mathrm{TPP}-\left(\mathrm{PEO}_{750}\right)_{4}$, and its high-catalytic activity for the oxidative cleavage of alkenes, resulting in the corresponding carbonyl compounds.

\section{Results and discussion}

Preparation of MnCl-TPP- $\left(\mathrm{PEO}_{750}\right)_{4}$ is depicted in Scheme 1. Incorporation of $\mathrm{PEO}$ side chain was achieved by direct alkylation of [TPP- $\left.(\mathrm{OH})_{4}\right]$ with $\mathrm{CH}_{3}\left(\mathrm{OCH}_{2} \mathrm{CH}_{2}\right)_{16} \mathrm{OTs}$ in $88 \%$ yield. ${ }^{1} \mathrm{H}$ NMR spectra of TPP- $\left(\mathrm{PEO}_{750}\right)_{4}$ showed characteristic shifts at $8.82(8 \mathrm{H})$ for the pyrrole methine protons and a singlet at $2.79 \mathrm{ppm}$ for the $\mathrm{NH}$ protons in the pyrrole unit. In addition, the integration ratio of ethylene protons for $-\mathrm{OCH}_{2} \mathrm{CH}_{2}$ - versus pyrrole methine protons confirmed the tetraalkylation on the porphyrin moiety. Treatment of TPP- $\left(\mathrm{PEO}_{750}\right)_{4}$ with $\mathrm{MnCl}_{2}$ under basic conditions afforded the desired complex in $93 \%$ yield. Characterization of this complex was performed via UV-vis and elemental analysis. The characteristics $\mathrm{UV}$-vis spectrum of $\mathrm{MnCl}-$ TPP- $\left(\mathrm{PEO}_{750}\right)_{4}$ in $\mathrm{CH}_{2} \mathrm{Cl}_{2}$ is similar to that of $\mathrm{MnCl}-\mathrm{TPP}$, proving the formation of manganese complex. ${ }^{21,25}$ This complex is soluble in water as well as in most organic solvents, and its UV-vis spectrum in water is essentially identical to that in dichloromethane.

To examine the catalytic activity, oxidation of alkenes with oxidants over the prepared metal complex was investigated (Table 1). The oxidation reaction of styrene, in the presence of $\mathrm{MnCl}-\mathrm{TPP}-\left(\mathrm{PEO}_{750}\right)_{4}$ as the catalyst, was first studied under air or $\mathrm{H}_{2} \mathrm{O}_{2}$. In this reaction, however, trace of benzaldehyde was obtained as the product even with the addition of imidazole, which acted as an axial ligand for the metal 


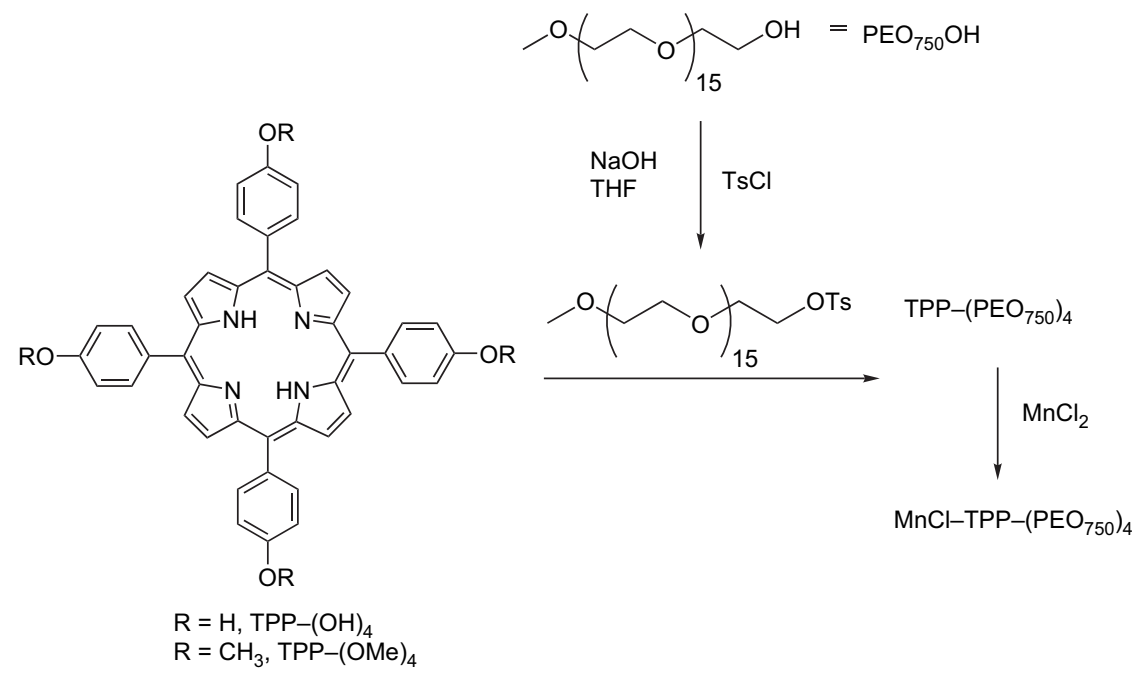

Scheme 1. Preparation of the manganese porphyrin complex.

complex. ${ }^{26}$ Alternatively, using sodium periodate as the oxidant in $\mathrm{CH}_{2} \mathrm{Cl}_{2} / \mathrm{H}_{2} \mathrm{O}(1: 1 \mathrm{v} / \mathrm{v})$, a similar catalytic reaction at room temperature revealed better conversion efficiency of turning styrene into a mixture of benzaldehdye and phenylacetaldehyde (see Table 1, entry 1). It is believed that the production of phenylacetaldehyde is mainly via the epoxidation of styrene, followed by the isomerization. ${ }^{11}$ Furthermore, as shown in entry 2 , the selectivity of the reaction improved significantly by using acetonitrile/water $(2: 1 \mathrm{v} / \mathrm{v})$ as solvent. For elevating temperatures (see entries 3 and 4 ), benzaldehyde became the exclusive product under similar conditions.
In view of the above results, the manganese catalytic system with $\mathrm{NaIO}_{4}$ and imidazole in acetonitrile/water rendered the best yield for oxidative cleavage of olefins and was followed in the following studies. Subsequently, various alkenes were tested under this catalytic system and the results are summarized in Table 1. Except for simple 1-alkenes, olefinic substrates underwent the oxidative cleavage to give the corresponding carbonyl compounds in excellent isolated yields. For the phenyl-disubstituted alkene such as 1-diphenylethene, benzophenone (ketones) was observed to be the major product (entry 6). Oxidative cleavage of cycloalkenes proceeded smoothly at room temperature to give the

Table 1. Catalytic oxidation of various alkenes catalyzed by $\mathrm{MnCl}-\mathrm{TPP}-\left(\mathrm{PEO}_{750}\right)_{4}{ }^{\mathrm{a}}$

\begin{tabular}{|c|c|c|c|c|c|c|c|}
\hline Entry & Substrate & Cat. $^{\text {b }}$ & $\mathrm{NaIO}_{4}{ }^{\mathrm{b}}$ & Imidazole $^{\mathrm{b}}$ & $\mathrm{Temp}^{\mathrm{c}}$ & Product & Yield $^{\mathrm{d}}(\%)$ \\
\hline 1 & Styrene (in $\mathrm{CH}_{2} \mathrm{Cl}_{2}$ /water) & 0.003 & 2.5 & 1.0 & $\mathrm{rt}$ & $\mathrm{PhCHO}, \mathrm{PhCH}_{2} \mathrm{CHO}$ & 44,30 \\
\hline 2 & Styrene & 0.003 & 1.5 & 1.0 & $\mathrm{rt}$ & $\mathrm{PhCHO}$, styrene oxide & 51,11 \\
\hline 3 & Styrene & 0.003 & 4.0 & 1.0 & 60 & $\mathrm{PhCHO}$ & 66 \\
\hline 4 & Styrene & 0.003 & 4.0 & 1.0 & 80 & $\mathrm{PhCHO}$ & 97 \\
\hline 5 & $m-\mathrm{ClC}_{6} \mathrm{H}_{4} \mathrm{CH}=\mathrm{CH}_{2}$ & 0.003 & 4.0 & 1.0 & 80 & $m-\mathrm{ClC}_{6} \mathrm{H}_{4} \mathrm{CHO}$ & 96 \\
\hline 6 & 1,1-Diphenylethene & 0.01 & 7.0 & 3.0 & 80 & Benzophenone & 99 \\
\hline 7 & 1-Methylstyrene & 0.003 & 4.0 & 1.0 & $\mathrm{rt}$ & Acetophenone & 99 \\
\hline 8 & trans-Stilbene & 0.01 & 7.0 & 3.0 & 80 & $\mathrm{PhCHO}$ & 87 \\
\hline 9 & 2-Vinylpyridine & 0.01 & 7.0 & 3.0 & 80 & $\begin{array}{l}\text { 2-Vinylpyridineoxide, } \\
\text { 2-Pyridinecarbaldehyde }\end{array}$ & 70,25 \\
\hline 10 & Cyclohexene & 0.0013 & 3.0 & 0.5 & $\mathrm{rt}$ & 1,6-Hexanedial & 97 \\
\hline 11 & Styrene oxide & 0.0013 & 3.0 & 0.5 & rt & $\mathrm{PhCHO}$ & 99 \\
\hline 12 & Cyclohexene oxide & 0.0013 & 3.0 & 0.5 & $\mathrm{rt}$ & 1,6-Hexanedial & 96 \\
\hline 13 & Cyclopentene & 0.0013 & 3.0 & 0.5 & rt & 1,5-Pentanedial & 99 \\
\hline 14 & Cyclooctene & 0.01 & 4.0 & 0.5 & $\mathrm{rt}$ & 1,8-Octanedial & 65 \\
\hline 15 & Benzyl alcohol & 0.03 & 7.0 & 3.0 & 80 & $\mathrm{PhCHO}$ & 60 \\
\hline 16 & Diphenylacetylene & 0.01 & 7.0 & 3.0 & 80 & - & - \\
\hline 17 & 1-Phenylcyclohexene & 0.01 & 4.0 & 0.5 & $\mathrm{rt}$ & 6-Phenyl-6-oxohexanal & 77 \\
\hline 18 & Tartaric acid & 0.01 & 4.0 & 1.0 & rt & - & - \\
\hline 19 & Norbornylene & 0.01 & 7.0 & 1.0 & rt & Cyclopentane-1,3-dicarbaldehyde & 33 \\
\hline 20 & $( \pm)$-Limonene & 0.01 & 3.0 & 1.0 & rt & (+)-4-Methyl-3-(3-oxobutyl)-4-pentenal & 89 \\
\hline 21 & $\alpha$-Pinene & 0.01 & 4.0 & 1.0 & $\mathrm{rt}$ & $\begin{array}{l}\text { (3-Acetyl-2,2-dimethylcyclobutyl)- } \\
\text { acetaldehyde }\end{array}$ & 44 \\
\hline $22^{\mathrm{e}}$ & Styrene & 0.003 & 4.0 & 1.0 & 80 & $\mathrm{PhCHO}$ & 97 \\
\hline
\end{tabular}

${ }^{a}$ Reaction conditions: substrate $(1 \mathrm{mmol})$ in $\mathrm{CH}_{3} \mathrm{CN}(2 \mathrm{ml}) / \mathrm{H}_{2} \mathrm{O}(1 \mathrm{ml})$ for $24 \mathrm{~h}$.

b In mmol.

c Oil bath temperature in ${ }^{\circ} \mathrm{C}$

${ }^{d}$ Isolated yield, except entries 1 and 2 by NMR integration.

e Under nitrogen atmosphere. 
corresponding di-aldehyde in excellent yields (entries 10, 13, and 14). Interestingly, a mixture of 2-pyridine epoxide (70\%) and 2-pyridinecarbaldehdye (25\%) was obtained from 2 -vinylpyridine under similar reaction conditions. It was also found that simple $\alpha$-olefins or terminal alkenes such as 1-octene, 1-hexene, carvone, $\beta$-pinene, and 2-methylhexene did not undergo the oxygenation, as supported by the starting material that is quantitatively recovered. In addition, the oxidation did not take place on alkyne or $\alpha, \beta$-unsaturated carbonyl compounds, the results of which are in sharp difference from the traditional methods. We thus tentatively concluded that for the $\mathrm{MnCl}-\mathrm{TPP}-\left(\mathrm{PEO}_{750}\right)_{4}$ catalytic reaction, the internal double bond of limonene was cleaved to yield the corresponding carbonyl functions, while the terminal one remained intact (entry 20), demonstrating its remarkable selectivity.

Oxidation of styrene oxide and cyclohexene oxide with a low loading of catalyst $(0.13 \%)$ rendered benzaldehyde and 1,6-hexanedial as the desired products, respectively (entries 11 and 12) at room temperature. These results provided a support to illustrate this oxygenation involving the epoxide intermediate, which was subsequently hydrolyzed to yield the 1,2-diol and then $\mathrm{C}-\mathrm{C}$ cleavage (Scheme 2). In addition, it was found that the cleavage of epoxide was much faster than that of olefin, suggesting that the rate limiting step of this oxidative cleavage is the formation of epoxide.

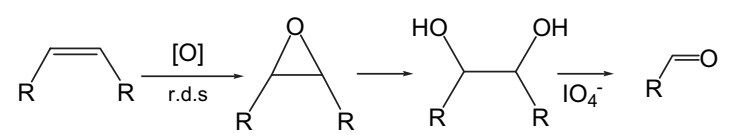

Scheme 2. Pathway for oxidative cleavage.

Figure 1 shows the difference of $\mathrm{MnCl}-\mathrm{TPP}-\left(\mathrm{PEO}_{750}\right)_{4}$ and $\mathrm{MnCl}-\mathrm{TPP}-(\mathrm{OMe})_{4}$ as catalysts for the oxidative cleavage of styrene. It is noticed that the formation of styrene oxide

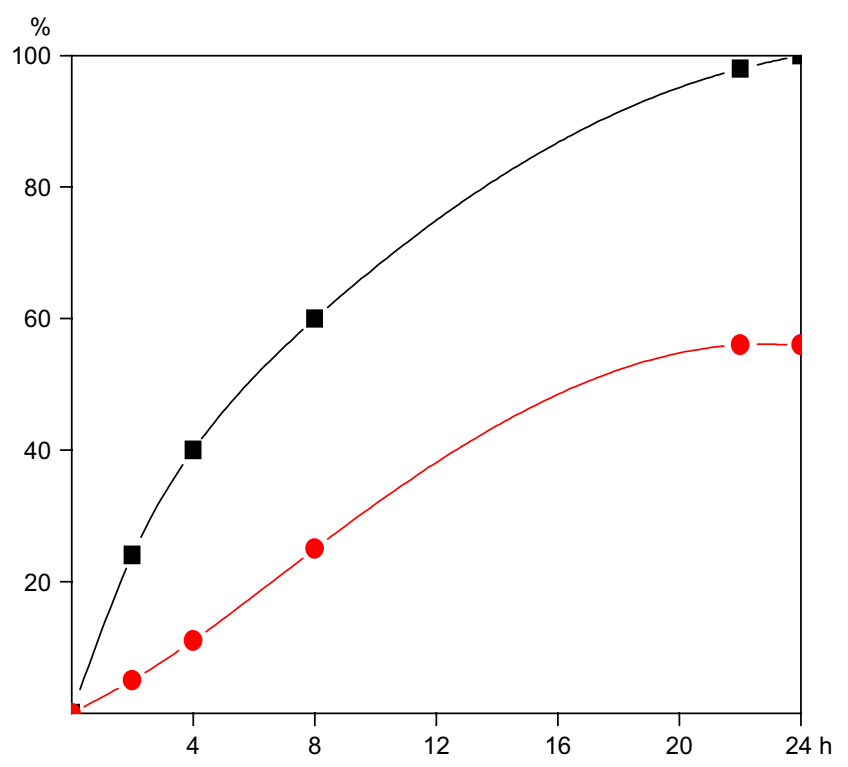

Figure 1. Plot of yields (benzaldehyde) versus time for the oxidative cleavage of styrene by $\mathrm{MnCl}-\mathrm{TPP}-\left(\mathrm{PEO}_{750}\right)_{4}(\boldsymbol{\square})$ and $\mathrm{MnCl}-\mathrm{TPP}-(\mathrm{OMe})_{4}(\boldsymbol{O})$. Reaction conditions: styrene $(1 \mathrm{mmol}), \mathrm{NaIO}_{4}(4 \mathrm{mmol})$, and imidazol (1 mmol) in $\mathrm{CH}_{3} \mathrm{CN}(2 \mathrm{ml}) / \mathrm{H}_{2} \mathrm{O}(1 \mathrm{ml})$ at $80{ }^{\circ} \mathrm{C}$. is not observed during this study, presumably its highly activity toward cleavage. As illustrated, styrene was completely converted into benzaldehyde with the use of $\mathrm{MnCl}-\mathrm{TPP}-$ $\left(\mathrm{PEO}_{750}\right)_{4}$ as the catalyst within $24 \mathrm{~h}$, but the referenced catalyst $\mathrm{MnCl}-\mathrm{TPP}-(\mathrm{OMe})_{4}$ only reached up to $55 \%$ under the similar reaction conditions. It appears that the activity of the polyether attached catalyst is much better than the un-modified one, indicating the neediness of polyether linkage on this catalyst for good activity.

To investigate the active oxidizing species in this catalysis, we performed a reaction of $\mathrm{MnCl}-\mathrm{TPP}-\left(\mathrm{PEO}_{750}\right)_{4}$ with equal molar amount of methylimidazole and $\mathrm{NaIO}_{4}$ in water. The UV-vis spectrum of the resulting solution showed the initial formation of a periodate-Mn species $\left(\lambda_{\max }=476 \mathrm{~nm}\right)$, and then the conversion into a high valent $\mathrm{Mn}$-oxo species (Soret $\lambda_{\max }=405 \mathrm{~nm}$ ) ${ }^{26}$ but this species was slowly diminished. By the addition of styrene to this solution, the oxidation product was formed. This observation suggests that the oxidation process might involve either a periodate-Mn complex or a Mn-oxo species.

The re-use of catalyst is also possible for this catalytic system. After the completion of the reaction, the organic products were removed from the water layer. The aqueous portion with the catalyst is ready for the further re-use. In order to investigate the stability and duration of active catalyst, the leaching of metal into the product mixture was determined after three reaction cycles. From analysis, no detectable leaching of manganese could be found, suggesting that the catalytic species remains in aqueous solution. The results of the oxidation of styrene into benzaldehyde over the catalyst with different reaction cycles are listed in Table 2 . It is noticed that the activity of catalyst slowly decreases along with the repeated cycles, presumably due to the accumulation of salt in aqueous phase. Under the similar conditions, the replacement of catalyst $\mathrm{MnCl}-\mathrm{TPP}-\left(\mathrm{PEO}_{750}\right)_{4}$ with $\mathrm{MnCl}-\mathrm{TPP}-(\mathrm{OMe})_{4}$ provided less than $60 \%$ of the cleavage product, and the catalyst was mixed with organic products, which was not easily separated, i.e. the re-use of $\mathrm{MnCl}-\mathrm{TPP}-(\mathrm{OMe})_{4}$ as a catalyst is not practical.

Table 2. Oxidation of styrene by the re-used catalyst $\mathrm{t}^{\mathrm{a}}$

\begin{tabular}{|c|c|c|c|c|}
\hline Run & 1 & 2 & 3 & 4 \\
\hline Yield $^{\mathrm{b}}(\%)$ & 97 & 85 & 83 & 75 \\
\hline
\end{tabular}

In summary, modification of the porphyrin moiety with four poly(ethylene glycol) chains allows TPP- $\left(\mathrm{PEO}_{750}\right)_{4}$ to be soluble in both organic and water solutions. Using this unique property, we have developed the manganese-based catalytic oxidation methods for the cleavage of a wide range of olefins to produce aldehydes. As this catalyst is easy to handle and is much less toxic than $\mathrm{OsO}_{4}$, this cleavage method is green-chemistry oriented and is expected to be useful in a variety of organic syntheses. Works focusing on detailed mechanistic pathway and the extension of this system to other oxygenation reactions are currently in progress. 


\section{Experimental}

\subsection{General}

Nuclear magnetic resonance spectra were recorded in $\mathrm{CDCl}_{3}$ or acetone- $d_{6}$ on either a Bruker AM-300 or AVANCE 400 spectrometer. Chemical shifts are given in parts per million relative to $\mathrm{Me}_{4} \mathrm{~S}$ for ${ }^{1} \mathrm{H}$ NMR. Infrared spectra were measured on a Nicolet Magna-IR 550 spectrometer (Series-II) as $\mathrm{KBr}$ pellets, unless otherwise noted. Chemicals and solvents were of analytical grade and used as received unless otherwise stated. TPP- $(\mathrm{OMe})_{4}$ was prepared according to the reported methods. ${ }^{27}$

\subsubsection{Preparation of $5,10,15,20$-tetrakis(4-hydroxy-} phenyl)porphyrin $\left[\mathbf{T P P}-(\mathrm{OH})_{4}\right]$. The porphyrin TPP$(\mathrm{OMe})_{4}(1 \mathrm{~g}, 1.3 \mathrm{mmol})$ was dissolved in $30 \mathrm{~mL}$ of dichloromethane with stirring. To this, borontribromide $(8.1 \mathrm{~g}$, $32.6 \mathrm{mmol})$ in dichloromethane $(5 \mathrm{~mL})$ was added slowly. The resulting mixture was stirred for $12 \mathrm{~h}$ at room temperature and then was quenched with $5 \mathrm{~mL}$ of methanol and neutralized with ammonia solution till the solution turned from green to dark red color. The mixture was evaporated till dryness, extracted with ethyl acetate and the organic layer was washed several times with water. It was separated, dried over anhydrous magnesium sulfate, filtered, and concentrated. The residue was chromatographed on silica gel with acetone/light petroleum (1:1) to yield pure compound [TPP$\left.(\mathrm{OH})_{4}\right]\left(0.8 \mathrm{~g}, 87 \%\right.$ yield). ${ }^{27} \mathrm{IR}$ (neat) $3330.4,1613.3$, 1513.8, 1248.6, 1182.3, $804.4 \mathrm{~cm}^{-1}$. ${ }^{1} \mathrm{H}$ NMR $(400 \mathrm{MHz}$, acetone- $\left.d_{6}\right) \delta 8.91(\mathrm{~s}, 8 \mathrm{H}), 8.86(\mathrm{~s}, 4 \mathrm{H}), 8.05(\mathrm{~d}, J=8.4 \mathrm{~Hz}$, $8 \mathrm{H}), 7.29(\mathrm{~d}, J=6.5 \mathrm{~Hz}, 8 \mathrm{H}),-2.70(\mathrm{~s}, 2 \mathrm{H})$.

3.1.2. Preparation of $\mathrm{CH}_{3}\left(\mathrm{OCH}_{2} \mathrm{CH}_{2}\right)_{16} \mathrm{OTs}$. Sodium hydroxide $(3.65 \mathrm{~g}, 91.3 \mathrm{mmol})$ and poly(ethylene glycol) methylether $\mathrm{CH}_{3}\left(\mathrm{OCH}_{2} \mathrm{CH}_{2}\right)_{16} \mathrm{OH}(45.70 \mathrm{~g}, 60.9 \mathrm{mmol})$ were dissolved in a mixture of THF $(140 \mathrm{~mL})$ and water $(20 \mathrm{~mL})$. A solution of $p$-toluenesulfonyl chloride $(12.76 \mathrm{~g}$, $67.0 \mathrm{mmol}$ ) in $20 \mathrm{~mL}$ of THF was added slowly to the above solution at ice-cooled temperature. The solution was stirred at $0{ }^{\circ} \mathrm{C}$ for $3 \mathrm{~h}$ and then at room temperature for $12 \mathrm{~h}$ and then poured into $50 \mathrm{~mL}$ of ice water. The mixture was extracted several times with methylene chloride. The combined organic layers were washed with dilute $\mathrm{HCl}$ followed by brine and then dried over magnesium sulfate. After filtration, the solvent was removed under reduced pressure to give the desired tosylate $\left(41 \mathrm{~g}, 75 \%\right.$ yield). ${ }^{1} \mathrm{H}$ NMR $(400 \mathrm{MHz}$, $\left.\mathrm{CDCl}_{3}\right) \delta 7.77(\mathrm{~d}, J=7.6 \mathrm{~Hz}, 2 \mathrm{H}), 7.32(\mathrm{~d}, J=7.6 \mathrm{~Hz}, 2 \mathrm{H})$, $4.14(\mathrm{t}, J=4.8 \mathrm{~Hz}, 2 \mathrm{H}), 3.67(\mathrm{t}, J=4.0 \mathrm{~Hz}, 2 \mathrm{H}), 3.65-3.56$ $(\mathrm{m}, 60 \mathrm{H}), 3.54-3.51(\mathrm{~m}, 2 \mathrm{H}), 3.35(\mathrm{~s}, 3 \mathrm{H}), 2.43(\mathrm{~s}, 3 \mathrm{H})$. These data are similar to those reported. ${ }^{28}$

3.1.3. Preparation of TPP- $\left(\mathrm{PEO}_{750}\right)_{4}$. A mixture of [TPP- $\left.(\mathrm{OH})_{4}\right](1 \mathrm{~g}, 1.47 \mathrm{mmol})$ and $\mathrm{CH}_{3}\left(\mathrm{OCH}_{2} \mathrm{CH}_{2}\right)_{16} \mathrm{OTs}$ $(5.32 \mathrm{~g}, 5.89 \mathrm{mmol})\left[\mathrm{Ts}=p-\mathrm{CH}_{3} \mathrm{C}_{6} \mathrm{H}_{4} \mathrm{SO}_{2}-\right]$ was dissolved in $50 \mathrm{~mL}$ of dimethylformamide. To this, potassium carbonate $(0.81 \mathrm{~g}, 5.9 \mathrm{mmol})$ was added and the solution was stirred at $80^{\circ} \mathrm{C}$ for $16 \mathrm{~h}$. After cooling to room temperature, the solution was poured into water and extracted thrice with methylene chloride. The combined organic layers were washed with water and then with brine, dried over magnesium sulfate, filtered, and the solvent was removed at reduced pressure. Chromatography (silica, ether/acetone,
1:3) was employed to furnish the pure product $(4.80 \mathrm{~g}$, $88 \%$ yield). $\mathrm{UV}-$ vis $\left(\varepsilon, \mathrm{CH}_{2} \mathrm{Cl}_{2}\right): \lambda_{\max } 421\left(3.6 \times 10^{5}\right), 517$ $\left(2.3 \times 10^{4}\right), 555\left(1.6 \times 10^{4}\right), 596\left(9.2 \times 10^{3}\right), 649\left(1.0 \times 10^{4}\right)$. ${ }^{1} \mathrm{H}$ NMR $\left(400 \mathrm{MHz}, \mathrm{CDCl}_{3}\right) \delta 8.82(\mathrm{~s}, 8 \mathrm{H}), 8.08(\mathrm{~d}$, $J=8.8 \mathrm{~Hz}, 8 \mathrm{H}), 7.27(\mathrm{~d}, J=8.8 \mathrm{~Hz}, 8 \mathrm{H}), 4.41(\mathrm{t}, J=5.2 \mathrm{~Hz}$, $8 \mathrm{H}), 4.04(\mathrm{t}, J=4.8 \mathrm{~Hz}, 8 \mathrm{H}), 3.87-3.61(\mathrm{~m}, 232 \mathrm{H}), 3.54$ $3.51(\mathrm{~m}, 8 \mathrm{H}), 3.34(\mathrm{~s}, 12 \mathrm{H}),-2.79(\mathrm{~s}, 2 \mathrm{H})$. Anal. Calcd for $\mathrm{C}_{176} \mathrm{H}_{294} \mathrm{~N}_{4} \mathrm{O}_{68}: \mathrm{C}, 59.48 ; \mathrm{H}, 8.34 ; \mathrm{N}, 1.58$. Found: $\mathrm{C}$, 59.00; H, 8.09; N, 2.02.

3.1.4. Preparation of $\mathrm{MnCl}-\mathrm{TPP}-\left(\mathrm{PEO}_{750}\right)_{4}$. The porphyrin $(1 \mathrm{~g}, 0.28 \mathrm{mmol})$ was dissolved in $50 \mathrm{~mL}$ of refluxing DMF for several minutes and $\mathrm{MnCl}_{2} \cdot 4 \mathrm{H}_{2} \mathrm{O}(0.16 \mathrm{~g}$, $0.84 \mathrm{mmol}$ ) was added to the solution. The solution was allowed to reflux for $30 \mathrm{~min}$. The reaction was monitored by TLC. DMF was distilled off and the resulting syrupy oil was chromatographed on silica gel with $\mathrm{CH}_{2} \mathrm{Cl}_{2}-\mathrm{MeOH}$ $(10: 1)$ as an eluent to give the desired complex as green solid $(0.93 \mathrm{~g}, \quad 93 \%$ yield $)$. UV-vis $\left(\varepsilon, \mathrm{CH}_{2} \mathrm{Cl}_{2}\right): \lambda_{\max } 380$ $\left(8.7 \times 10^{4}\right), 407\left(8.2 \times 10^{4}\right), 481\left(1.7 \times 10^{4}\right), 533\left(1.2 \times 10^{4}\right)$, $587\left(1.7 \times 10^{4}\right), \quad 627 \quad\left(2.5 \times 10^{4}\right)$. Anal. Calcd for $\mathrm{C}_{176} \mathrm{H}_{292} \mathrm{ClMnN}_{4} \mathrm{O}_{68} \cdot 2 \mathrm{H}_{2} \mathrm{O}: \mathrm{C}, 57.46 ; \mathrm{H}, 8.11 ; \mathrm{N}, 1.52$. Found: C, 57.86; H, 8.04; N, 1.76 .

\subsection{Catalysis-general procedure}

A mixture of $\mathrm{MnCl}-\mathrm{TPP}-\left(\mathrm{PEO}_{750}\right)_{4}, \mathrm{NaIO}_{4}$, imidazole, and the substrate was placed in a round bottomed flask. Solvents were added to this mixture. The reaction was heated with stirring at $80-100{ }^{\circ} \mathrm{C}$ for a certain period of hours under aerobic conditions. The progress of the reaction was monitored by ${ }^{1} \mathrm{H}$ NMR spectrometer. For various substrates, the reaction mixture was extracted with ether, which was then filtered through a short column of silica gel. The filtrate was evaporated under reduced pressure or distilled off to give the desired product. Oxidative cleavage products obtained in this work were characterized by spectral methods particularly with ${ }^{1} \mathrm{H}$ NMR and the data were consistent with those reported.

3.2.1. $p$-Chlorobenzaldehdye. ${ }^{29}{ }^{1} \mathrm{H}$ NMR $(400 \mathrm{MHz}$, $\left.\mathrm{CDCl}_{3}\right) \delta 9.96(\mathrm{~s}, 1 \mathrm{H}), 7.80(\mathrm{~d}, J=8.0 \mathrm{~Hz}, 2 \mathrm{H}), 7.49(\mathrm{~d}$, $J=8.1 \mathrm{~Hz}, 2 \mathrm{H})$.

3.2.2. Benzophenone. ${ }^{30}{ }^{1} \mathrm{H}$ NMR $\left(400 \mathrm{MHz}, \mathrm{CDCl}_{3}\right)$ $\delta$ 7.79-7.76 (m, 4H), $7.56(\mathrm{t}, J=7.0 \mathrm{~Hz}, 2 \mathrm{H}), 7.45(\mathrm{tt}$, $J=7.0,1.4 \mathrm{~Hz}, 4 \mathrm{H})$.

3.2.3. Acetophenone. ${ }^{30}{ }^{1} \mathrm{H}$ NMR $\left(400 \mathrm{MHz}, \mathrm{CDCl}_{3}\right) \delta 7.92$ $(\mathrm{d}, J=7.6 \mathrm{~Hz}, 2 \mathrm{H}), 7.50(\mathrm{t}, J=7.6 \mathrm{~Hz}, 2 \mathrm{H}), 7.42(\mathrm{dd}, J=7.6$, $8.0 \mathrm{~Hz}, 2 \mathrm{H}), 2.55$ (s, 3H).

3.2.4. 2-Vinylpyridineoxide. ${ }^{31}{ }^{1} \mathrm{H} \quad \mathrm{NMR} \quad(400 \mathrm{MHz}$, $\left.\mathrm{CDCl}_{3}\right) \delta 8.52(\mathrm{~d}, J=4.8 \mathrm{~Hz}, 1 \mathrm{H}), 7.51-7.48(\mathrm{~m}, 1 \mathrm{H})$, $7.22-7.19(\mathrm{~m}, 2 \mathrm{H}), 3.97(\mathrm{t}, J=4.0 \mathrm{~Hz}, 1 \mathrm{H}), 3.14(\mathrm{dd}$, $J=10.3 \mathrm{~Hz}, 1 \mathrm{H}), 2.90(\mathrm{dd}, J=8.2 \mathrm{~Hz}, 1 \mathrm{H})$.

3.2.5. 2-Pyridinecarbaldehyde. ${ }^{31}{ }^{1} \mathrm{H}$ NMR $(400 \mathrm{MHz}$, $\left.\mathrm{CDCl}_{3}\right) \delta 10.05(\mathrm{~s}, 1 \mathrm{H}), 8.80(\mathrm{~d}, J=4.8 \mathrm{~Hz}, 1 \mathrm{H}), 7.90(\mathrm{~d}$, $J=5.2 \mathrm{~Hz}, 1 \mathrm{H}), 7.82$ (t, $J=3.6 \mathrm{~Hz}, 1 \mathrm{H}), 7.51-7.48(\mathrm{~m}, 1 \mathrm{H})$.

3.2.6. 1,6-Hexanedial. ${ }^{\mathbf{3 2}}{ }^{1} \mathrm{H} \mathrm{NMR}\left(400 \mathrm{MHz}, \mathrm{CDCl}_{3}\right) \delta 9.74$ (t, $J=3.4 \mathrm{~Hz}, 2 \mathrm{H}), 2.45-2.43(\mathrm{~m}, 4 \mathrm{H}), 1.64-1.61(\mathrm{~m}, 4 \mathrm{H})$. 
3.2.7. 1,5-Pentanedial. ${ }^{32}{ }^{1} \mathrm{H}$ NMR $\left(400 \mathrm{MHz}, \mathrm{CDCl}_{3}\right)$ $\delta 9.75(\mathrm{t}, J=2.4 \mathrm{~Hz}, 2 \mathrm{H}), 2.50(\mathrm{~m}, 4 \mathrm{H}), 1.96-1.91(\mathrm{~m}, 2 \mathrm{H})$.

3.2.8. 1,8-Octanedial. ${ }^{33}{ }^{1} \mathrm{H} \mathrm{NMR}\left(400 \mathrm{MHz}, \mathrm{CDCl}_{3}\right) \delta 9.75$ (t, $J=3.4 \mathrm{~Hz}, 2 \mathrm{H}), 2.41-2.38(\mathrm{~m}, 4 \mathrm{H}), 1.59-1.55(\mathrm{~m}, 4 \mathrm{H})$, $1.34-1.30(\mathrm{~m}, 4 \mathrm{H})$.

3.2.9. 6-Phenyl-6-oxohexanal. ${ }^{34}{ }^{1} \mathrm{H}$ NMR $(400 \mathrm{MHz}$, $\left.\mathrm{CDCl}_{3}\right) \delta 9.74(\mathrm{t}, J=1.6 \mathrm{~Hz}, 1 \mathrm{H}), 7.93-7.91(\mathrm{~m}, 2 \mathrm{H}), 7.52$ (t, $J=7.6 \mathrm{~Hz}, 1 \mathrm{H}), 7.44-7.43(\mathrm{~m}, 2 \mathrm{H}), 2.96(\mathrm{t}, J=6.8 \mathrm{~Hz}$, $2 \mathrm{H}), 2.48-2.45(\mathrm{~m}, 2 \mathrm{H}), 1.75-1.70(\mathrm{~m}, 4 \mathrm{H})$.

3.2.10. Cyclopentane-1,3-dicarbaldehyde. ${ }^{35}{ }^{1} \mathrm{H} \quad \mathrm{NMR}$ $\left(400 \mathrm{MHz}, \mathrm{CDCl}_{3}\right) \delta 9.63(\mathrm{~d}, J=2.0 \mathrm{~Hz}, 2 \mathrm{H}), 2.83-2.74$ (m, 2H), 2.30-2.14 (m, 2H), 1.98-1.85 (m, 2H), 1.81-1.74 (m, 2H).

3.2.11. ( \pm )-4-Methyl-3-(3-oxobutyl)-4-pentenal. ${ }^{36} \quad{ }^{1} \mathrm{H}$ NMR $\left(400 \mathrm{MHz}, \mathrm{CDCl}_{3}\right) \delta 9.64(\mathrm{t}, J=4.5 \mathrm{~Hz}, 1 \mathrm{H}), 4.82-$ $4.74(\mathrm{~m}, 2 \mathrm{H}), 2.65-2.60(\mathrm{~m}, 1 \mathrm{H}), 2.56-2.30(\mathrm{~m}, 4 \mathrm{H}), 2.10$ (s, 3H), 1.68-1.60 (m, 5H).

3.2.12. (3-Acetyl-2,2-dimethylcyclobutyl)acetaldehyde. ${ }^{37}$ ${ }^{1} \mathrm{H}$ NMR $\left(400 \mathrm{MHz}, \mathrm{CDCl}_{3}\right) \delta 9.70(\mathrm{t}, J=2.8 \mathrm{~Hz}, 1 \mathrm{H})$, 2.90-2.87 (m, 1H), 2.44-2.40 (m, 3H), 2.03 (s, 3H), 1.95$1.93(\mathrm{~m}, 2 \mathrm{H}), 1.36(\mathrm{~s}, 3 \mathrm{H}), 0.87(\mathrm{~s}, 3 \mathrm{H})$.

\section{Acknowledgements}

This work was partially supported by the National Science Council, Taiwan, ROC for the financial support (NSC942113-M002-035).

\section{References and notes}

1. Meunier, B. Chem. Rev. 1992, 92, 1411.

2. Collman, J. P.; Zhang, X.; Lee, V. J.; Uffelman, E. S.; Brauman, J. I. Science 1993, 261, 1404.

3. Feiters, M. C.; Rowan, A. E.; Nolte, R. J. M. Chem. Soc. Rev. 2000, 29, 375.

4. Boulatov, R. Pure Appl. Chem. 2004, 76, 303.

5. Meunier, B.; Bernadou, J. Top. Catal. 2002, 21, 47.

6. Rosenthal, J.; Pistorio, B. J.; Chng, L. L.; Nocera, D. G. J. Org. Chem. 2005, 70, 1885.

7. Nam, W.; Park, S.-E.; Lim, I. K.; Lim, M. H.; Hong, J.; Kim, J. J. Am. Chem. Soc. 2003, 125, 14674.

8. Patra, A. K.; Afshar, R. K.; Rowland, J. M.; Olmstead, M. M.; Mascharak, P. K. Angew. Chem., Int. Ed. 2003, 42, 4517.

9. De Visser, S. P.; Shaik, S. J. Am. Chem. Soc. 2003, 125, 7413.
10. Funyu, S.; Isobe, T.; Takagi, S.; Tryk, D. A.; Inoue, H. J. Am. Chem. Soc. 2003, 125, 5734.

11. Chen, J.; Che, C.-M. Angew. Chem., Int. Ed. 2004, 43, 4950.

12. Li, Z.; Xia, C.-G. Tetrahedron Lett. 2003, 44, 2069.

13. Sundn, H.; Engqvist, M.; Casas, J.; Ibrahem, I.; Córdova, A. Angew. Chem., Int. Ed. 2004, 43, 6532.

14. Poriel, C.; Ferrand, Y.; Le Maux, P.; Rault-Berthelot, J.; Simonneaux, G. Tetrahedron Lett. 2003, 44, 1759.

15. Goh, Y. M.; Nam, W. Inorg. Chem. 1999, 38, 914.

16. Goto, Y.; Watanabe, Y.; Fukuzumi, S.; Dinnocenzo, J. P. J. Am. Chem. Soc. 1980, 120, 10762.

17. Jones, R.; Jayaraj, K.; Gold, A.; Krik, M. L. Inorg. Chem. 1998, 37, 2742.

18. Brule, E.; de Miguel, Y. R.; Hii, K. K. Tetrahedron 2004, 60, 5913.

19. Mohajer, D.; Tayebee, R.; Goudarziafshar, H. J. Chem. Res. Synop. 1999, 168.

20. Tangestaninejad, S.; Habib, M. H.; Mirkhani, V.; Moghadam, M. J. Chem. Res. Synop. 2001, 444.

21. Benaglia, M.; Danelli, T.; Pozzi, G. Org. Biomol. Chem. 2003, $1,454$.

22. Kuehn, F. E.; Fischer, R. W.; Herrmann, W. A.; Weskamp, T.; Transition Metals for Organic Synthesis, 2nd ed.; Wiley-VCH: Weinheim, 2004; Vol. 2, pp 427-436 and references therein.

23. Bäckvall, J.-E. Modern Oxidation Methods; Wiley-VCH: Weinheim, 2004.

24. Adler, A. D.; Longo, F. R.; Finarelli, J. D.; Goldmacher, J.; Assour, J.; Korsakoff, L. J. Org. Chem. 1962, 32, 476.

25. Rothemund, P.; Menotti, A. R. J. Am. Chem. Soc. 1940, 70, 1808.

26. Mohajer, D.; Karimipour, G.; Bagherzadeh, M. New J. Chem. 2004, 28, 740 .

27. Milgrom, L. R. J. Chem. Soc., Perkin Trans. 1 1983, 2535.

28. Bahr, J. L.; Yang, J.; Kosynkin, D. V.; Bronikowski, M. J.; Smalley, R. E.; Tour, M. J. Am. Chem. Soc. 2001, 123, 6356.

29. Stoop, R. M.; Bachmann, S.; Valentini, M.; Mezzetti, A. Organometallics 2000, 19, 4117.

30. Ley, S. V.; Ramarao, C.; Lee, A. L.; Ostegaard, N.; Smith, S. C.; Shirley, I. M. Org. Lett. 2003, 5, 185.

31. Bernasconi, S.; Orsini, F.; Sello, G.; Colmegna, A.; Galli, E.; Bestetti, G. Tetrahedron Lett. 2000, 47, 9157.

32. Nagarkatti, J. P.; Ashley, K. R. Tetrahedron Lett. 1973, 46, 4599.

33. Yang, D.; Zhang, C. J. Org. Chem. 2001, 66, 4814.

34. Hon, Y. S.; Lin, S. W.; Lu, L.; Chen, Y. J. Tetrahedron 1995, 51, 5019.

35. Goksu, S.; Altundas, R.; Sutbeyaz, Y. Synth. Commun. 2000, 30, 1615

36. Ronchetti, F.; Toma, L. Tetrahedron 1986, 42, 6535.

37. Barton, D. H. R.; Fontana, G. Synth. Commun. 1996, 26, 1953. 